\title{
Geophysical characterization in aid for geological reconnaissance of Manganese occurrence
}

\author{
César Augusto Moreira ${ }^{1}$; Rafael Paes $^{2}$; Leandro Balarin Vieira ${ }^{3}$; \\ 1, 2,3 Instituto de Geociências e Ciências Exatas. Universidade Estadual Paulista - UNESP - Rio Claro (SP)
}

Copyright 2014, SBGf - Sociedade Brasileira de Geofísica

Este texto foi preparado para a apresentação no VI Simpósio Brasileiro de Geofísica Porto Alegre, 14 a 16 de outubro de 2014. Seu conteúdo foi revisado pelo Comitê Técnico do VI SimBGf, mas não necessariamente representa a opinião da SBGf ou de seus associados. É proibida a reprodução total ou parcial deste material para propósitos comerciais sem prévia autorização da SBGf.

\begin{abstract}
The geological mapping in mineral exploration is a basic procedure widely used for lithological description, structural survey or recognition of mineralization indicators. Lateritic coverage is considered as an important indicator of the ore presence, which has its genesis and evolution often associated with primary deposits. However, this coverage extension and thickness in many cases makes it impossible to evaluate the primary deposit in depth by geological surveys. In this case, geophysical methods can be a fast and low cost alternative in this exploration phase, due to the physical properties contrast between ore and host rocks. This paper presents a study case in which a DC Resistivity geophysical method is applied in assistance to geological recognition of a manganese occurrence in surface and ore body delimitation in depth. The results allow to define an extensive lateritic coverage and a restrict area of gondites in surface, but continuous in depth.
\end{abstract}

\section{Introdution}

Geological survey is one of the basic procedures employed in exploratory activities for mineral prospection. It's detailing and scale varies within each research phase and depends on financial availability.

The basic geological mapping for mineral prospection are focused in particularity regarding the reconnaissance of features that are associated to mineral deposits models in lithological, pedological, structural and stratigraphical aspects (Moon et al., 2000).

Several mineral deposits are recognizable due to texture differences, as weathering or color patterns that are distinct to that of the host rock, which can result in geomorphological expressions like valleys or outstanding highs in the relief (Maranhão, 1985). Weathering products of iron and manganese enriched rocks are generically described as laterites, originate by accumulation of metallic oxides and hydroxides and form gossans and iron hat structures overlying primary metallic deposits.

Lateritic horizons can frequently result in secondary deposits and can serve as indicator for primary deposits. Characteristic aspects, as dark or orange colors, massive habit, layered arrangement and surface position, contrasting with soils or saprolites host. These aspects are quite relevant and considered in geological mapping for mineral exploration purposes.

During the supergenic enrichment process, metallic ions are leached in surface, mobilized from the weathering profile in the deep and precipitates in environments that present conditions for chemical stability, generally associated to the dry-satured soil interface, where active oxidation and mineral neoformation occurs at specific ph and Eh conditions.

The weathering and deposition of metallic ions is a process with important economic implications due to the chemical elements concentration (Moon et al., 2000).

However, this vertical migration process also depends on cimentation due to seasonal variations of groundwater and preferred directions of groundwater flows. Therefore, the spacial extension of supergenic deposits is frequently much high when compared in dimension area to the primary deposits, which can in many cases, difficult to estimate mineral deposits dimensions in preliminary stages of mineral exploration.

This paper presents and discuss a combined interpretation of geological and geophysical data obtained in an area that has a mineral occurrence of manganese described by Angeli et al. (2011), in the region of Itapira, São Paulo state. The objective are order to evaluate surface dimensions of this occurrence and ore typology in its geological aspects, and the geophysical characterization of the ore and its continuity in subsurface.

\section{Materials and methods}

The study area is located in Itapira city, São Paulo state, southeastern Brazil, 177 km far from São Paulo city.

The regional geological context is represented by the Ribeira Fold Belt (CPRM, 2003) and the rocks in the region of study can be grouped in two main lithostratigraphic units: Amparo Complex and Itapira Group.

The structures and rocks of the Amparo Complex reveal polimetamorphic classical evolution, initiated by clastic and clay minerals sedimentation concomitant with intrusions, extrusions and basic tuffs. These rocks resulted in gneissic-migmatitic association of amphibolite facies and granulite in a metamorphic event assigned to the Mesoproterozoic. In a successive event of tectonic deformation recrystallization and intrusion of large granitic masses occur, which resulted in new migmatization in Brazilian Cycle (CPRM, 2003). 
The Itapira Group is composed of metasedimentary rocks originated by prograding shallow platform sediments, composed predominantly of muscovite quartzites and paragneisses, and less frequently migmatites, calcsilicate rocks, schists, metaultramafic rocks, marbles, metasediments of Eleuterio Formation and lenses of gondites (CPRM, 2003).

The metasedimentary rocks of Itapira Group, directly associated with gondites, represent metamorphic lithologies generated from a plataformal progradational sequence, consisting of muscovite schist, talc schist, muscovite quartzite, quartzite interbedded with mafic and ultramafic rocks, whose foundation is represented by migmatitic and gneissic rocks of the Amparo Complex. The evidence suggests active tectonic environment with rapid transport of immature sediments of volcanic contribution to the genesis of manganifer protomineral in the study area (Verissimo, 1991).

More than a dozen gonditic bodies were discovered in the region, which present in a greater or lesser extent, classic profiles of weathering alteration with enrichment in oxides and hydroxides of manganese. The genetic processes of supergene enrichment of the manganese protomineral are attributed to events that occurred between the Eocene and the Miocene, related to the formation of the South American Surface, attributed to climatic variations and tectonic reactivation (King, 1956).

The manganese protomineral found in the Itapira Group is classified regarding the genesis in: silicate protomineral composed mainly of quartz and spessartite in approximately similar proportions, and calcium silicate, with quartz, spessartite, pyroxenes, amphiboles, plagioclase, carbonates and epidote (Angeli et al., 2011).

The geological recognition consisted in local mapping for identification of the lateritic and gonditic manganese. In the area three ore types were classified (Figure 1):

- Lateritic manganese and quartzite fragments, present in slope, with gradual predominance of rocks fragments in the topographic lower part direction.

- Layered lateritic manganese, characterized by lamination blocks and massive surface levels with variable fracturing, dark gray, predominant in plane relief.

- Gonditic blocks occur in topographic elevation, characterized by massive dark blocks, with quartz-feldspatic veins.

Informations obtained by description of the few lateritic and gonditic ores exposed in the region prevented morphology or continuity inferences of ore bodies in depth. This fact motivated the development of geophysical studies, based on the contrast of physical properties between ore and country-rock.

Several studies have shown the advantages, disadvantages, benefits and limitations of this DC Resistivity geophysical methods used in mineral exploration, with emphasis for morphological characterization of sulfide and oxides deposits, along with metalogenetic evolution analysis (Irvine \& Smith, 1990; White et al., 2001; Moreira et al., 2012; Moreira et al., 2014).

This work employed DC Resistivity geophysical method. Variations in the resistivity of earth materials, either vertically or laterally, produce variations in the relations between applied current and potential distribution as measured on the surface, thereby revealing something about the composition, extent, and physical properties of the subsurface materials (Telford et al., 2004). Properties that affect the resistivity of a soil or rock include porosity, water content, composition (clay mineral and metal content), salinity and grain size distribution (Keller \& Frischknecht, 1996).

The DC Resistivity method is based on generating an electric field in subsurface by injecting an electric current (I) through an electronic device represented by metal stems, called transmitter circuit (Orellana, 1972). The electric potential $(\Delta V)$ is produced by the passage of this field and captured by a receiver circuit, which can also be represented by metallic rods. Applying Ohm's Law considering the electrode spacing, represented by a factor called $\mathrm{K}$, enables the measuring of the apparent resistivity parameter $(\rho a)$ for various depth levels (equation 1):

$$
\rho a=K \quad \frac{\Delta V}{I} \text { Ohm.m }
$$

(equation 1)

For data acquisition it was adopted the electrical profiling technique for electrical resistivity assessment, with investigation of 11 levels in depth through a WennerSchlumberger array. This array is characterized by the use of electrodes oriented linearly, injection of an electric current and acquisition of potential differences of georreferenciated pairs of electrodes regarding a central point.

It was adopted a $10 \mathrm{~m}$ spacing between electrodes and 11 depth levels were investigated. A Terrameter SAS 4000 resistivity meter was used, which consists on a single module for transmitting and receiving data with a resolution of $1 \mathrm{mV}, 100 \mathrm{~W}$ of power and four reading channels, calibrated for transmission of periodic cycles of low frequency alternating current, a procedure that enables noise filtering during data acquisition (ABEM, 2006). In the area $690 \mathrm{~m}$ of electrical profiling were performed, divided in 3 lines of $230 \mathrm{~m}$ in radial array and 1200 of spacing among lines (Figure 1).

\section{Results and Discussions}

The data acquired in the field were tabulated and processed in the Res2Dinv program (Geotomo Software, 2011), where models of inversion sections with distance and depth were generated, together with topographic correction (Figure 2). 
The inversion process consists in the superposition of a series of rectangular blocks connected to the distribution of field points in the pseudo section, i.e. the section generated by the field data in theoretical depth. The depth of the bottom row of blocks is set to be approximately equal to the equivalent depth of investigation of points with the greatest space between the electrodes (Edwards, 1977).

The subroutine of direct modeling is used to calculate the values for apparent resistivity, and a nonlinear optimization technique for minimum squares is used for reversal routine (DeGroot-Hedlin \& Constable 1990, Loke \& Barker, 1996). The result is presented in the form of section with distance versus depth in terms of pseudo section, calculated section and inversion model. This paper presents only resistivity inversion model (Figure 2).

In the three sections is possible to identify a pattern characterized by high resistivity values (above $5000 \Omega$.m), between $120 \mathrm{~m}$ and $160 \mathrm{~m}$ from the lines beginning, continuous in subsurface until $25 \mathrm{~m}$, the highest depth reached after data processing. In this interval lateritic fragments and gondite massive blocks crossed by quartzfeldspatic veins are found at surface.

However, between $0 \mathrm{~m}$ and $120 \mathrm{~m}, 160 \mathrm{~m}$ and 190m intervals, high values of electrical resistivity (above $5000 \Omega . m$ ), are located only near the surface. During geological survey in surface lateritic fragments with quartzite fragments and layers of massive laterite were described. In these intervals in depth predominate low

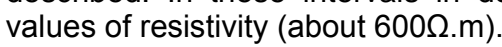

Direct relations between high values of resistivity near the surface in areas of ore occurrence, suggest that high resistivity in depth correspond to continuity of mineralizations in subsurface, apparently with dip towards the beginning of the lines (hence north).

The central interval in surface where gondite with quartzfeldspatic veins predominate is probably continuous in depth, since minerals like quartz, feldspar and oxides are electrical insulators and, even with the presence of local groundwater, produces an outstanding contrast with the surrounding country-rock.

During the geological survey stage, quartzites and quartzschists were described beyond the lateritic areas, with the quartzite being a more resistant lithotype regarding weathering process, which is responsible for the generation of soils and lateritic surfaces. The set of laterite fragments and quartzite is predominantly in dry conditions, characteristics that transform this horizon into an electrical insulator, in other words, justify the high values of resistivity obtained.

Areas in depth where low values of resistivity predominates are likely attributed to humidity, by the aquifer level and the presence of clay minerals by hydration of phyllosilicates where schists prevail.

\section{Conclusions}

Using both geological and geophysical data allowed a quite reasonable assessment of the mineral occurrence, with lateral and in depth delimitation of the potential mineralized area. The broad contrast of electrical resistivity between ore and country-rock can be related to mineral assemblage and presence of free aquifer level.

The action of physical, chemical and biological processes in lithotypes as quartz schists, originates soils and saprolites enriched in clay minerals by hydration of phyllosilicates, gradually removed from shallow portions of the weathering profile by infiltration or laminar flux of meteoric waters. The residual profile ends up being enriched in dry quartzite fragments and lateritic material, characterized by high resistivity.

The presence of phyllosilicates in subsurface foliated rocks enables retention of humidity, which by the absence of oxides and hydroxides, justifies low values of resistivity

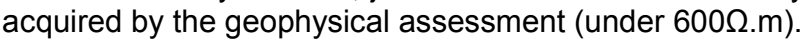

The manganese ore is basically composed by manganese oxides and hydroxides, also showing spessartite and quartz-feldspatic veins. This mineral assemblage is characterized by high resistivity both at the

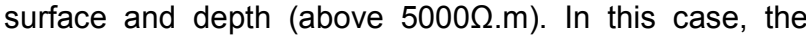
electrical resistivity parameter proved to be a relevant indicator for primary evaluation of mineral deposits of supergene origin.

Lateritic coverages represent important indicators of mineralizations target during geological reconnaissance in mineral exploration, which in many cases prevent the evaluation of mineral potential in the area in this research phase. Therefore, the geophysical prospection in aid for geological reconnaissance can be an alternative for preliminary investigations in depth, to delimitate targets for drilling and sampling in order to submit them for quantification by chemical analysis.

\section{Acknowledgments}

The author's thanks a FUNDUNESP (Fundação de Desenvolvimento da UNESP - $n^{\circ}$ 02/2014-PROPe) by financial support.

\section{References}

Angeli, N.; Khan, H.; Ito, G. M.; Carvalho, S. G.; JimenezRueda, J.; Penha, U.C. Geologia e Caracterização Tecnológica do Minério de Manganês da Mina Córrego do Cocho, Itapira (SP). Geologia USP série Científica, v. 11, no3, p. 107-130, 2011. Access in http://www.scielo.br/pdf/rem/v64n3/a08.pdf.

Companhia de Pesquisas e Recursos Minerais - CPRM. 2003. Geologia, Tectônica e Recursos Minerais do Brasil. CPRM, Brasília, 692p.

DeGroot-Hedlin, C. \& Constable, S. Occam's inversion to generate smooth, two-dimensional models form magnetotelluric data. Geophysics. v. 55, p. 1613-1624, 1990. 
Edwards, L. S. A modified pseudosection for resistivity and induced polarization. Geophysics, v. 42, p.10201036, 1977.

Geotomo Software. Res2Dinv instructions manual, version 3.53. 2003. 129p.

Irvine, R. J. \& Smith, M. J. Geophysical exploration for Epitermal deposits. Journal of Geochemical Exploration, v. 36, p. $375-412,1990$.

Loke, M. H. \& Barker, R. D. Rapid least-squares inversion of apparent resistivity pseudosections by a quasi-Newton method. Geophysical Prospecting, $n^{0}$ 44, p. 131-152, 1996.

Keller, G.V. \& Frischknecht, F.C. 1966. Electrical methods in geophysical prospecting. New York: Pergamon Press, $562 p$.

King, L. C. A Geomorfologia do Brasil Oriental. Revista Brasileira de Geografia, Rio de Janeiro, v. 18, n², p.147265, 1956

Moreira, C. A.; Lopes, S. M.; Schweig, C.; Seixas, A. R. Geoelectrical prospection of disseminated sulfide mineral occurrences in Camaquã sedimentary basin, Rio Grande Sul State, Brazil. Revista Brasileira de Geofísica, v. 30, $\mathrm{n}^{02}$, p. 169-179, 2012. Access in http://www.scielo.br/pdf/rem/v64n3/a08.pdf.

Moreira, C. A.; Borges, R. M,; Vieira, G. M. L.; Malagutti Filho, W.; Montanheiro, M. A. F. Geological and geophysical data integration for delimitation of mineralized areas in a supergene manganese deposits. Geofísica Internacional, v. 53, n², p. 199-210, 2014. Access

in http://www.geofisica.unam.mx/unid_apoyo/editorial/public aciones/investigacion/geofisica_internacional/anteriores/2 014/02/7_moreira.pdf.

Orellana, E. Prospeccion Geoelectrica en Corriente Continua, Biblioteca Técnica Philips, Madrid: Paraninfo, 1972. 523p.

Telford, W. M.; Geldart, L. P.; Sheriff, R. E. 2004. Applied Geophysics. New York: Cambridge University Press, $2^{\circ}$ ed., $774 p$.

Veríssimo, C. U. Evolução geológica dos corpos de protominério e mineralizações de manganês associadas, porção leste de São Paulo e Sul de Minas Gerais. Rio Claro. Universidade Estadual Paulista, 1991. (Dissertação de Mestrado).
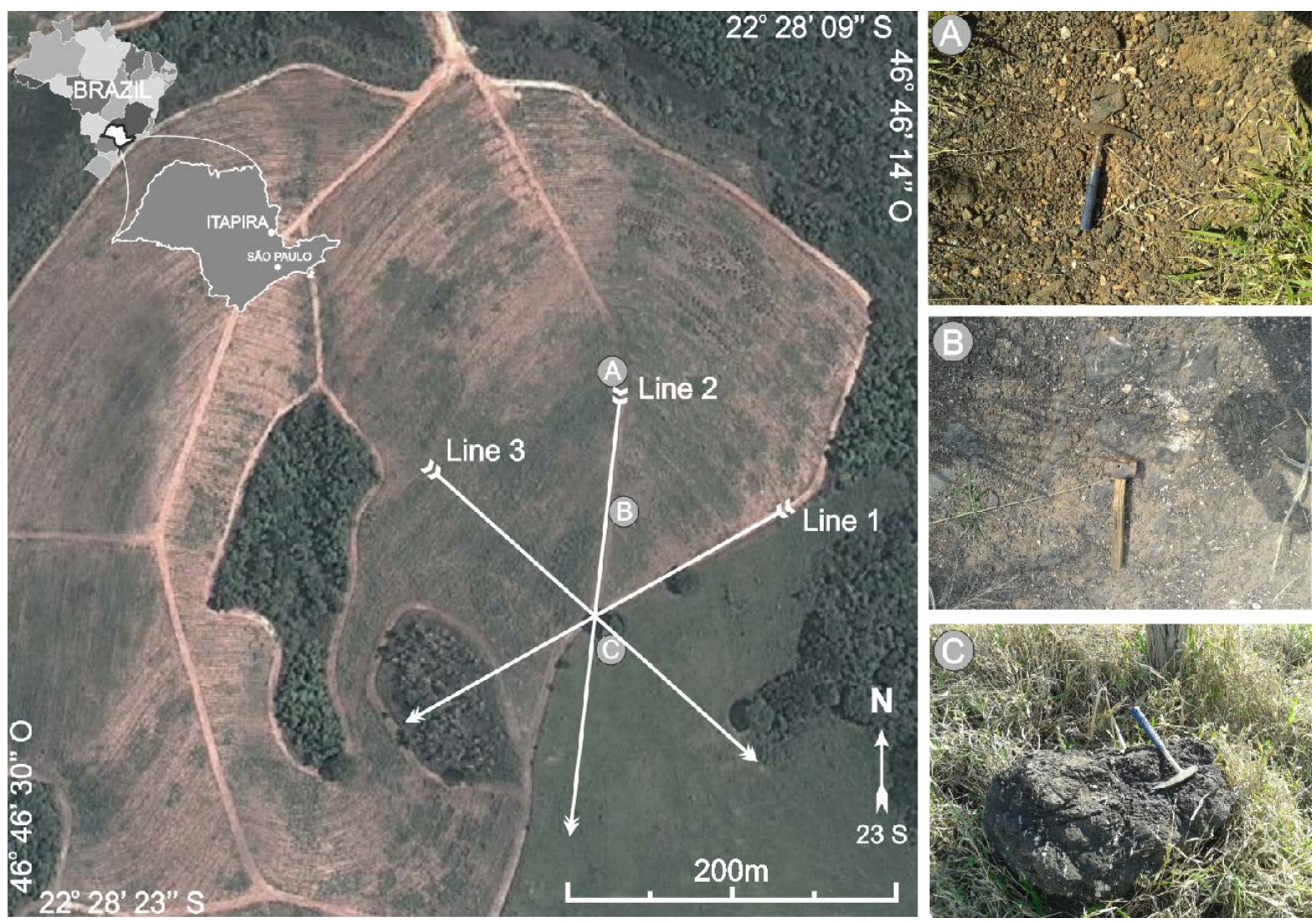

Figure 1 - Study area with electrical profiling lines. The featured points in the map are representative of the manganese mineralization. A) Lateritic manganese with quartzite fragments. B) Layered lateritic manganese. C) Gonditic ore in block. 

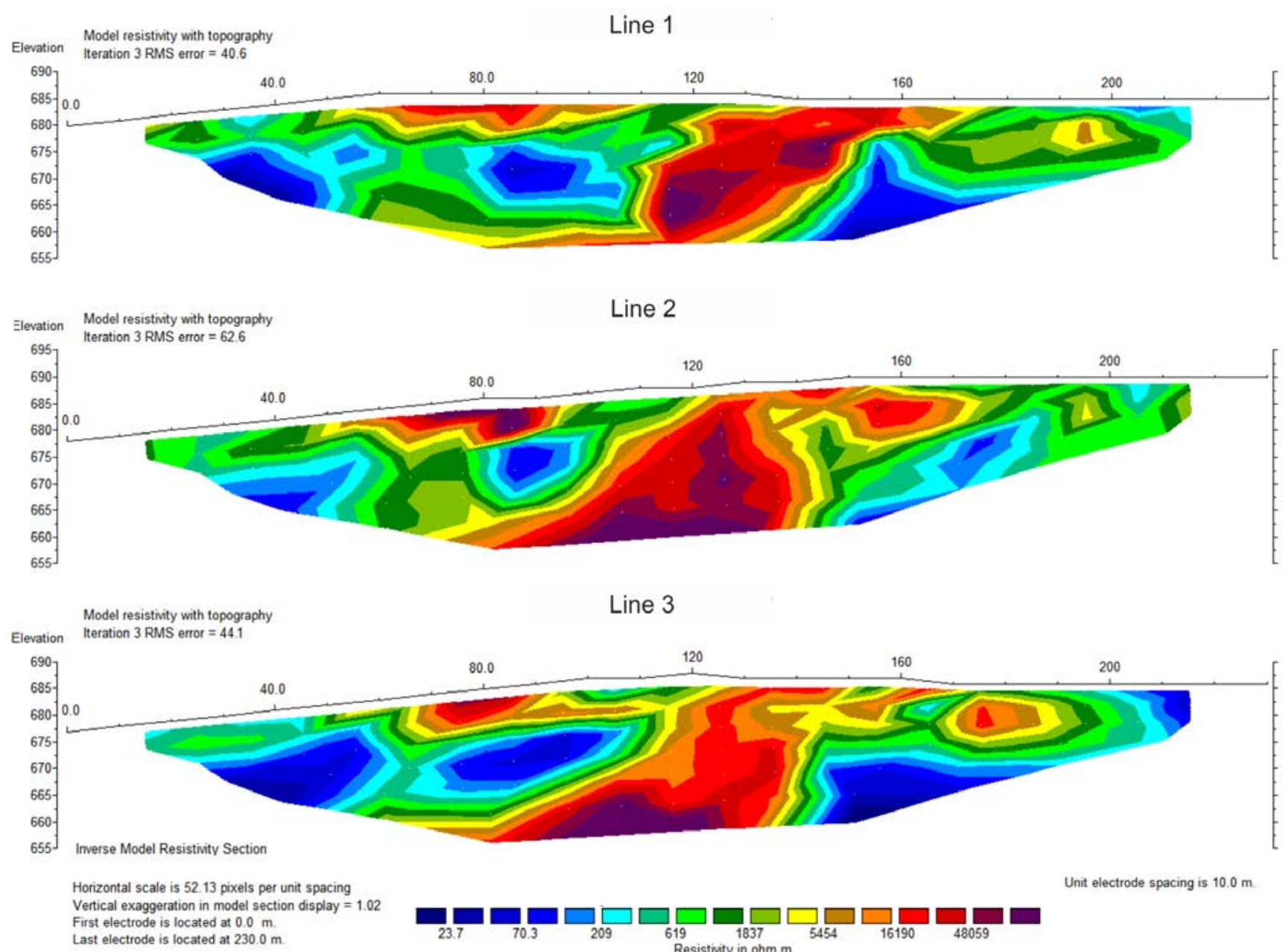

Figure 2 - Resistivity inversion models, with topographic correction, elevation and surface distance in meters 